\title{
Distribution, shape and clonal growth of the rare endemic tree Olea europaea subsp. laperrinei (Oleaceae) in the Saharan mountains of Niger
}

\author{
Fabien Anthelme • Afane Abdoulkader • \\ Guillaume Besnard
}

Received: 20 June 2006/ Accepted: 12 November 2007

(C) Springer Science+Business Media B.V. 2007

\begin{abstract}
The populations of the Laperrine's olive (Olea europaea subsp. laperrinei) are located in three main areas corresponding to the mountains of northern Niger (Aïr), southern Algeria (Hoggar), and north-western Sudan (western Darfur). The populations native of Niger were found to occur in very fragmented patches from 1550 to $1850 \mathrm{~m}$ in five isolated mountains with population sizes not exceeding 100 trees each, except in the Tamgak. Samples in the Tamgak and the Bagzane mountains were studied by combining field observations with identification of genets (using highly variable DNA marker analyzes). Trees were relatively small and multi-stemmed like those in the Hoggar, and were associated with some tropical species as in the western Darfur. They were found on borders of "wadis", i.e., temporary water courses, in ravines and on hillsides. They were unable to rely on sexual reproduction, which was found to be ineffective. In contrast, $28 \%$ of the genetic profiles
\end{abstract}

F. Anthelme $(\square)$

IRD, UR 136 and UMR 1097, 911 avenue Agropolis, BP 64501, Montpellier cedex 5 34394, France

e-mail: Anthelme@ird.fr

\section{A. Abdoulkader}

Département de Géographie, Université Abdou

Moumouni, Niamey, Niger

G. Besnard

Department of Ecology and Evolution, Biophore, University of Lausanne, Lausanne 1015, Switzerland found $\left(n_{\text {genet }}=98\right)$ were represented with two or more trees without aboveground connections. Molecular and morphological data both demonstrated that the populations used clonal growth (CG) to survive in the current unfavorable period of hyper-aridity, and thus are likely to be remnant populations. Signs of human-related disturbances, recorded on $43 \%$ of the sampled trees, should be a determining factor of distribution as well. In the Bagzane mountains especially, where human activities are more intense than in the Tamgak mountains, trees developed preferentially on hillsides and ravines with low access rather than on wadi borders with better edaphic conditions but easier access for livestock/ people. CG may be therefore, a survival strategy both against aridity and human-related disturbances. Sexual reproduction may be triggered during a less arid period, following the model of multiple demographic strategies, widespread in arid environments. However, survival would be affected by browsing and cuttings. Lastly, the absence of an efficient sexual strategy coupled with the high fragmentation of very small populations and a narrow altitudinal range of distribution indicates that today the populations of $O$. e. laperrinei in the Aïr mountain range are more endangered than those from southern Algeria and north-western Sudan.

Keywords Arid - Isolation · Habitat fragmentation · Human activities - Microsatellite markers .

Multiple demographic strategy $\cdot$ Remnant population 


\section{Introduction}

In the face of the sixth phase of species extinction, astonishing and for the first time generated by human beings (Vitousek et al. 1997; Chapin III et al. 2000), the urgent need for the conservation of biodiversity is global. It is particularly neglected in the developing countries of the Sahara. However, the desertification that has followed in the wake of a hyper-arid climatic phase (Le Houérou 1997) and the rapid growth of human populations, which leads to local overexploitation of the vegetation, invasion of exotic species and erosion (Anthelme et al. 2006), threaten to eradicate a large number of taxons that are resources for human populations and/or remarkable components of biodiversity through their endemism and their rarity (Child 2003; McNeely 2003). This threat applies especially to the ecosystems of the Saharan mountains of Niger, Africa, which are efficient refuges for vegetation diversity (Ozenda 2004), but are increasingly used as human-related resources for a few decades (Anthelme et al. 2006).

Among endangered taxa, Olea europaea L. subsp. laperrinei (Batt. and Trab.) Ciferri (Oleaceae) or Laperrine's olive is one of the most remarkable endemic tree taxa of the Sahara along with Myrtus nivellei and Cupressus dupreziana (Bruneau de Miré and Gillet 1956b; Quézel 1978; Abdoun and Beddiaf 2002). It belongs to the O. europaea complex and displays close affinities with the Mediterranean olive (Green 2002). However, genetic studies have recently revealed a complex biogeographic history for the Laperrine's olive populations, which may be due to recurrent migration events from both Mediterranean and Tropical Africa (Hess et al. 2000; Besnard et al. 2002, 2007). This wild olive tree also presents traits of potential interest for the cultivated olive. Particularly, it could be an important genetic resource for drought adaptation.

The distribution of the Laperrine's olive is limited to the Saharo-Sahelian mountain areas (Benichou 1962; Wickens 1976; Baali-Cherif and Besnard 2005; Fig. 1). In Algeria, it is found in the Hoggar mountain range, especially in the Atakor, the Tassili n'Immidir, the Tefedest, and the Tassili n'Ajjer mountains (Benichou 1962). In Niger, it has been identified in the Aïr mountain range in the southern Sahara and located precisely in three massifs: Greboun, Tamgak and Bagzane (Bruneau de Miré and Gillet 1956a). In
Sudan, the Laperrine's olive is present in the western Darfur (Jebel Marra and Jebel Gurgeil; Quézel 1969; Wickens 1976). Surprisingly, the Chadian mountain ranges of the Ennedi and the Tibesti do not harbour O. e. laperrinei today. However, fossils, indicating their existence as far back as the Pleistocene, have been discovered (Quézel 1978). Lastly, its presence in Morocco (Wickens 1976) was questioned (Maire 1933; Maley 1980) but finally refuted in favour of another endemic taxon, O. europaea subsp. maroccana (Médail et al. 2001; Vargas et al. 2001).

In all these mountain ranges, $O$. e. laperrinei is distributed only at elevations above $1200 \mathrm{~m}$ (Bruneau de Miré and Gillet 1956a, b; Quézel 1962, 1969; Wickens 1976; Poilecot 1996; Ozenda 2004). This characteristic makes it a Saharan mountain species sensu White (1983). While its numbers remain low overall, given its restricted area of distribution, $O$. $e$. laperrinei is frequently found in the Hoggar, the Tefedest, the Tassili n'Ajjer, (Quézel 1965), the Jebel Marra (Wickens 1976) and the Jebel Gurgeil (Quézel 1969). By comparison, the populations of the Laperrine's olive seem to be very limited in the Air mountain range (Quézel 1962; Poilecot 1996). The rarity of sexual reproduction is one of the most remarkable life-traits of $O$. $e$. laperrinei in the Hoggar (Quézel 1965; Baali-Cherif and Besnard 2005). This leads to think that these populations were relictual and may survive through clonal growth (CG), which can be a prevailing strategy of persistence in constrained environments (Honnay and Bossuyt 2005) under the respective influences of stress, disturbance, competition, or a combination (Anthelme et al. 2002). In contrast, sexual reproduction is efficient in Darfur where aridity is much lower (Wickens 1976; White 1983).

The populations in the Air mountain range have been poorly described, and data available are out of date and do not mention their reproduction strategies. In the Bagzane mountains, O. e. laperrinei was described only once (Bruneau de Miré and Gillet 1956a), and its existence is today questioned by the inhabitants themselves (Djibrilla unpublished data). However, as the populations of $O$. e. laperrinei in the Tibesti and Ennedi mountain ranges are now extinct, the populations of the Air are the last representatives of the Sahara-Sahel transition zone. Their conservation was thus made a priority during the establishment of the National Nature Reserve of the 
Fig. 1 Distribution of Olea europaea subsp. laperrinei in the Saharan-Sahelian region (grey areas)

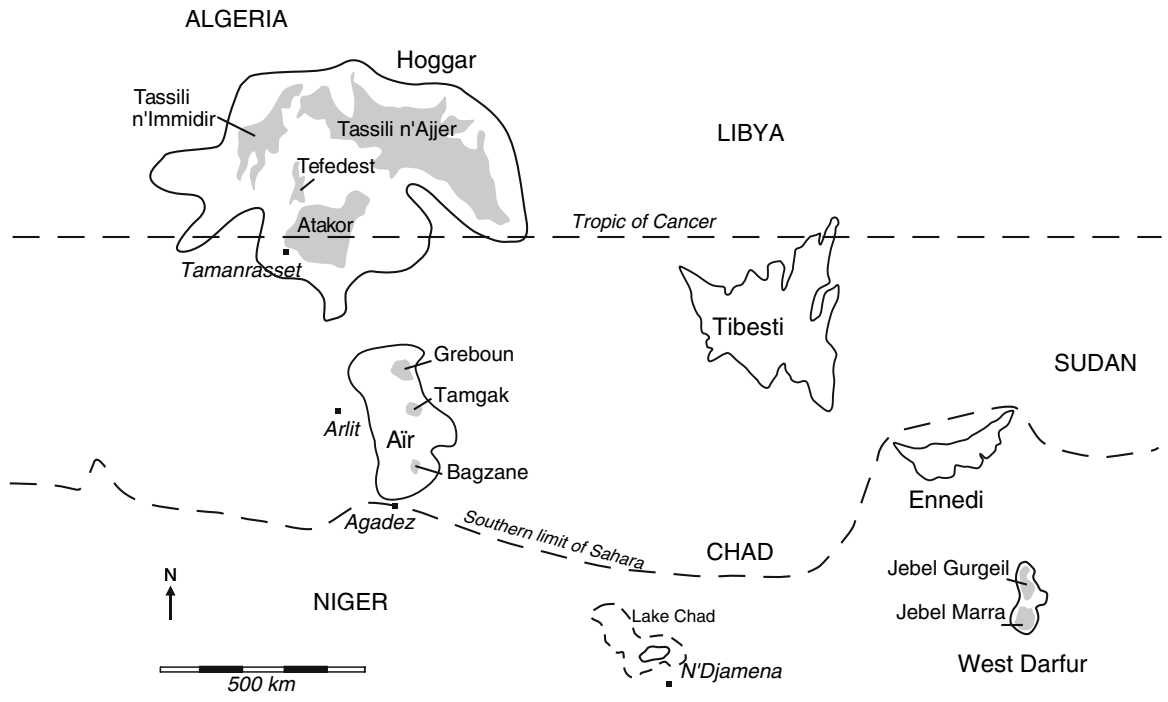

Aïr-Ténéré, but the means allocated to this task are non-existent.

Baali-Cherif and Besnard (2005) mentioned that $O$. e. laperrinei in the Hoggar (Algeria) was a small multistemmed tree, thus suggesting that the Laperrine's olive may use a vegetative strategy for its reproduction and persistence in arid environments. In contrast, in the wetter western Darfur, O. e. laperrinei was described as a tree reaching up to $15 \mathrm{~m}$ high without mention of a multi-stemmed shape (Quézel 1969; White 1983). Considering this variability, the description of its shape (height, maximal length at ground level if the tree is multi-stemmed) and the number of interconnected stems per tree should be relevant descriptors to understand the long-term dynamics of $O$. e. laperrine $i$ in the Airr. Taking into account that the Laperrine's olive has been described as strongly damaged by human-related disturbances in the Hoggar (Sahki and Sahki 2004) and in the western Darfur (Quézel 1969; Wickens 1976), signs of human-related damages should be relevant descriptors as well.

In parallel with a necessary description of the shape of O. e. laperrinei populations in the Airr, the focus of the study was to determine at which level their current persistence was dependent on CG, and if they follow the model of multiple demographic strategies, alternating sexual and asexual regenerations with changes in environmental constraints (Garcia and Zamora 2003). Based on hyper-variable microsatellite loci, genetic data extracted from leaves of $O$. e. laperrine $i$ were provided to test the existence of clonality, i.e., the occurrence of genets represented by several trees without aboveground connections. The shape, distribution and reproductive strategies of $O$. e. laperrinei were correlated with the biotic and abiotic environments by combining field observations with genotype identification.

\section{Material and methods}

Study area

The Aïr is an ancient crystalline mountainous complex located in northern Niger between $17^{\circ} \mathrm{N}$ and $20^{\circ} 30^{\prime} \mathrm{N}$ and $7^{\circ} 30^{\prime} \mathrm{E}$ and $10^{\circ} \mathrm{E}$, over an area of $61,500 \mathrm{~km}^{2}$ (Black et al. 1967). It forms part of the southern Sahara (Ozenda 2004) as an extension of the Hoggar (southern Algeria). The elevation ranges from $700 \mathrm{~m}$ (rocky plateaux and plains with wadis) to $2022 \mathrm{~m}$ at Idoukal n'Taghes in the Bagzane mountains. The mountains are crystalline, forming plateaux surrounded by cliffs, and displaying a few volcanic intrusions (Black et al. 1967).

The principal mountains, or massifs, are the Greboun, the Tamgak, the Taghmert, the Takolkouzet, the Goundai, the Egalah-Aroyan and the Bagzane (Fig. 2). They are isolated from one another by wide plains with wadis and/or rocky plateaux. While the Greboun mountains form an integral part of the Air range from the geological point of view (Black et al. 1967), they are differentiated by floristic criteria that are more closely related to the southern zones of the Hoggar in Algeria (Quézel 1962). 
The Bagzane mountains rise above the plains of the Aïr and cover an area of $40 \mathrm{~km}$ long and $20 \mathrm{~km}$ wide. The summit is a plateau (1400-1800 m) with a substratum made up of alternate layers of rock and clay-sand on granite or volcanic bedrock. Since the Neolithic age, the clay-sand zones have been a precious resource for settled populations who practice irrigated agriculture and free-range livestock farming (Adamou and Morel 2005). The Tamgak mountains cover an area substantially larger than that of the
Bagzane and their plateaux at the summit, located at the same elevation, are essentially rocky and granitic. Human populations have not taken permanent residence in these mountains that they use only occasionally for herding on an extensive basis (Giazzi 1996).

Rain falls from June to September and reaches between 20 and $100 \mathrm{~mm}_{\text {year }}{ }^{-1}$ at elevations under $1000 \mathrm{~m}$ (Giazzi 1996) with a high spatial variation. They decrease however from the south-western to the

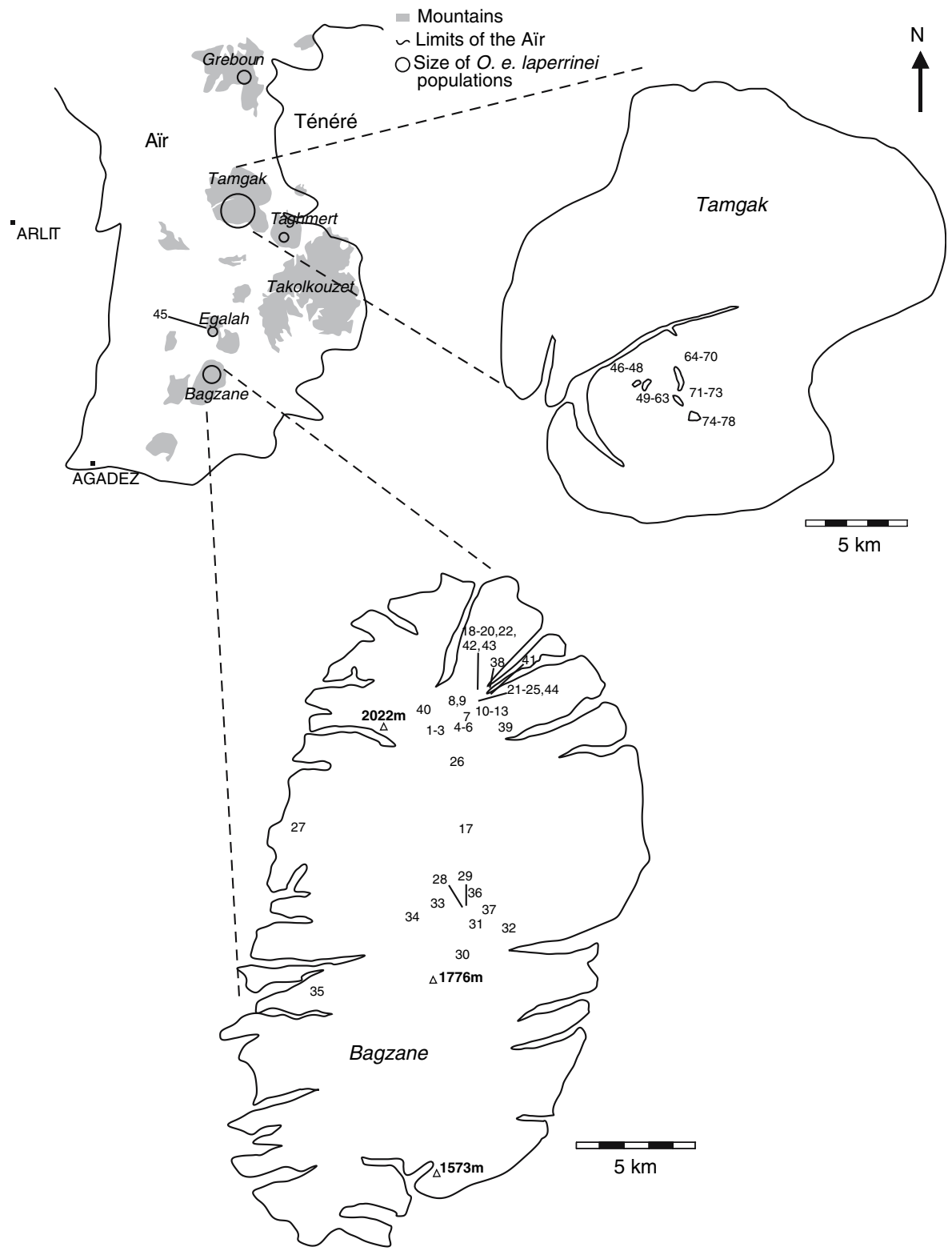

Fig. 2 Distribution and population sizes of Olea europaea subsp. laperrinei inside the Aïr mountain range. Focus on the site distribution in the Bagzane and Tamgak mountains ( $n=78$; see Appendix for correspondence between sites and location of trees) 
north-eastern corners of the mountain range whereas they increase with elevation (Gallaire 1995). Mean annual temperature at $700 \mathrm{~m}$ reaches $26.8^{\circ} \mathrm{C}$ (Giazzi 1996). On the high plateaux at elevations above $1500 \mathrm{~m}$, temperatures lower than $0^{\circ} \mathrm{C}$ are not rare in December and January. Soils are lithosols and regosols, often very thin (Giazzi 1996).

The vegetation belongs to three main groups (Poilecot 1996): (i) the inter-mountain vegetation is the richest, supplied with water by the wadis and divided into two large types: the banks of wadis dominated by Hyphaene thebaica, Faidherbia albida, Acacia nilotica subsp. nilotica and Salvadora persica, and the clay-sand plains dominated by two associated species, Acacia tortilis subsp. raddiana and Panicum turgidum (Anthelme et al. 2007); (ii) the mountain vegetation is distinguished by the introgression of some tropical species that avoid the arid plains, such as Commiphora africana, Acacia laeta, Acacia seyal (Schulz and Adamou 1994), as well as some Saharan mountain species, such as O. e. laperrinei, Lavandula antinae, Rumex vesicarius and Salvia aegyptiaca; (iii) the desert vegetation is very poor in species and scarce in the Airr mountain range. It is composed mostly of hemicryptophytes characteristic of sandy places in the southern Sahara, in particular Centropodia forskalii, Stipagrostis acutiflora and S. vulnerans (Poilecot 1999).

The vegetation cover degrades rapidly under the influence of disturbances caused by human-related activities. This is mainly assignable to the settlement of human populations in the urban centres of Arlit and Agadez (approximately 100,000 inhabitants each; Fig. 1), the intensification and mechanization of irrigated agriculture, and rapid population growth associated with the intensification of livestock farming (Anthelme et al. 2006). The establishment of a Nature Reserve in the eastern half of the Aïr (Fig. 1) has very little effect on the conservation of species and ecosystems because it is very poorly funded. Accordingly, the protection of the biodiversity in general and of O. e. laperrinei in particular depends today essentially on the goodwill of local residents and on the distance that separates them from the urban centers (Anthelme et al. 2006). Mountain ecosystems where O. e. laperrinei develops are less affected by recent changes because of a low accessibility. As an exception however, the Bagzane ecosystems are already outstandingly degraded and this has been related to the high local population density associated with free-range livestock farming, by goats essentially (Anthelme et al. 2006). This may constitute a threat for the maintenance of O. e. laperrinei populations, as for many other species.

Data collecting and processing

Of the three massifs where $O$. e. laperrinei has been previously described in the Air, the sampling was limited to the Bagzane and the Tamgak mountains. In both areas, the presence of $O$. e. laperrinei (in Tamasheq: Aleo) was detected through a combination of field observations and surveys among the local residents. Data were collected in August and September 2004 in the Bagzane and in April 2004 in the Tamgak. In addition, the Egalah, a small mountain in the north of the Bagzane, was quickly visited after local inhabitants hypothesized the existence of $O$. e. laperrinei there.

In the Bagzane mountains, sampling of trees was systematic as a result of the low number of individuals present. In the Tamgak mountains, the $O$. e. laperrinei population size was larger and consequently our tree sampling was limited to only one representative zone (Fig. 2; see Appendix for coordinates).

First, we studied vegetative features of O. e. laperrinei trees sampled on 78 sites across the massifs of the Bagzane, the Tamgak and the Egalah (Appendix). Trees were subjected to the following measurements: height of the highest stem, maximal length at ground level, circumference of the largest stem (when the tree is multi-stemmed) at $0.5 \mathrm{~m}$ above the soil surface, and signs of human-related damages (cuttings, browsing, harvesting, fire).

In order to assess the importance of CG in Niger populations, the genetic profile of each tree was characterized using nuclear DNA markers according to Baali-Cherif and Besnard (2005) by collecting a few leaves on each tree. DNAs were extracted from silica-dried leaves using a CTAB method (Besnard et al. 2000). Nine microsatellites (single strand repeat, SSR) loci were selected (Baali-Cherif and Besnard 2005): DCA1, DCA3, DCA8, DCA9, DCA14, DCA15, GAPU45, PA(ATT)2 and EMO03. Nuclear SSRs were chosen because, they reveal a higher level of polymorphism compared with other genetic markers (Belaj et al. 2003) allowing a robust genotype identification. The probability $\left(P_{\text {gen }}\right)$ that two sampled trees belonging to different genets would have the 
same genotype by chance was calculated according to Parks and Werth (1993). The trees with the same SSR profile, i.e., belonging to the same genet, were called clones (see Results). In addition, each tree generally displayed several stems that were interconnected at ground level (multi-stemmed trees), which was taken as a supplementary index of CG.

Additionally, we characterized the habitat where $O$. e. laperrinei trees were present. Among habitats, the ravines contrast with the hillsides due to the flow of water that is channelled and seasonal. They also contrast with the borders of 'wadis' (non-permanent water courses) by the absence of a bed and by much steeper walls. No trees were found on rocky plateaux or clay-sand plains in our sample. The following variables were taken into account: nature of substratum (granitic or volcanic), estimation of the slope gradient, elevation (GPS garmin $12 \mathrm{XL}$ ), and geographical coordinates (GPS). Relationships between $O$. e. laperrinei attributes and environmental variables were analyzed (ANOVA and $\mathrm{Chi}^{2}$ analyses when specific conditions were met) with Minitab 14 software (Minitab Ltd, Coventry, UK).

Lastly, the presence of trees, shrubs and the most frequent plant species were recorded at each site of $O$. e. laperrinei. Latin binomials for plants fitted those of the Conservatoire Botanique de la Ville de Genève (Database of the Flowering Plants of Africa South of the Sahara 2006).

\section{Results}

Size and distribution of populations

A total of 143 trees were recorded: (i) In the Bagzane mountains, we sampled 83 trees belonging to two separate areas, i.e., the northern and central parts of the massif (Fig. 2). Up to now, only the northern area was known to shelter $O$. e. laperrinei in the Bagzane (Bruneau de Miré and Gillet 1956a). O57 and O70 were the only trees located in the eastern area; (ii) In the Tamgak mountains, the presence of about 2000 trees was estimated based on observations of inhabitants. Only 58 trees were sampled in the southern valley of the central part of the massif ("Faille du Tamgak", Fig. 2); (iii) In the Egalah mountains, where $O$. e. laperrinei was reported for the first time, only two trees (O84 and O85) were found.
Sites of $O$. e. laperrinei ranged from 1550 to $1850 \mathrm{~m}$ (Appendix) while the highest point in the two massifs is approximately $2000 \mathrm{~m}$. They were distributed similarly across massifs at a mean elevation of $1704 \mathrm{~m}$ (ANOVA: $F=0.08, p \leq 0.773$ ) and they grew only on a granite substratum.

\section{Characteristics of recorded trees (Table 1)}

The height of trees averaged approximately $4 \mathrm{~m}$,

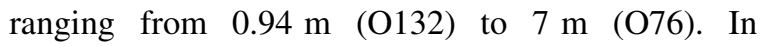
parallel, the maximal length of (multi-stemmed) trees at ground level averaged slightly less than $6 \mathrm{~m}$. As a general rule, it followed the direction of the slope gradient, it reached however $20 \mathrm{~m}$ for $\mathrm{O} 36$ (eight stems). The mean circumference of the thickest stem of trees was $0.61 \mathrm{~m}$, however that of $\mathrm{O} 119$ reached $3.84 \mathrm{~m}$, i.e., an estimated diameter of $1 \mathrm{~m}$. No significant difference was detected across the samples from the two massifs with regards to height, maximal length or circumference. Signs of human-related damages, mainly browsing and cutting of branches and/or stems, were found on almost half of the trees. Nevertheless, they were twice more frequent on trees from the Bagzane mountains than on trees from the Tamgak (Pearson $\mathrm{Chi}^{2}=6.72, p \leq 0.01$ ).

Fruiting was studied on samples from the Bagzane mountains $(n=81)$ and was found to be extremely rare. A few fruits were detected on $\mathrm{O} 25, \mathrm{O} 26$, and O29, i.e., less than $4 \%$ of the sampled trees. At the same time, no seedling and/or sapling was observed in either of the two massifs.

\section{Evidence for clonal growth}

Among the 133 DNA samples that could be extracted from trees, including two of the Egalah mountains, only 98 different genotype profiles (or genets) were detected (Appendix). The probability of obtaining the same genetic profile by chance $\left(P_{\text {gen }}\right)$ was negligible, ranging from $7 \times 10^{-5}(\mathrm{O} 15-\mathrm{O} 16)$ to $1 \times 10^{-11}$ (O62-O63), therefore, two trees with the same SSR profile were considered to correspond to a clone. Additionally, as reported by Baali-Cherif and Besnard (2005), a few cases of somatic mutations leading to three alleles at a locus were identified on trees O84 (DCA9; genotype 179-189-191) and O139 (DCA9; genotype 175-179-181). Additionally, trees 
Table 1 Olea e. laperrinei's characteristics in the Bagzane and the Tamgak, mean values with standard errors

\begin{tabular}{llll}
\hline & Bagzane $\left(n=83^{\mathrm{a}}\right)$ & Tamgak $(n=58)$ & Total \\
\hline Height of the highest stem (m) & $3.78 \pm 0.15$ & $4.03 \pm 0.15$ & $3.88 \pm 0.11$ \\
Maximal length at ground level (m) & $5.46 \pm 0.43$ & $5.99 \pm 0.37$ & $5.67 \pm 0.29$ \\
Circumference of the thickest stem (m) & $0.66 \pm 0.04$ & $0.55 \pm 0.08$ & $0.61 \pm 0.04$ \\
Trees with human-related damages (\%) & 61 & 33 & $43^{* *}$ \\
Trees with fruits (\%) & 3.7 & $-{ }^{\mathrm{b}}$ & $-{ }^{\mathrm{b}}$ \\
Juvenile sexual saplings & 0 & 0 & 0 \\
Genets with two or more clones (\%) & 40 & 13 & $28^{* *}$ \\
Number of stems per tree & $2.92 \pm 0.29$ & $4.00 \pm 0.32$ & $3.47 \pm 0.25$ \\
\hline
\end{tabular}

** $\mathrm{Chi}^{2}$ test significant at $p \leq 0.01$

a Except for signs of human-related damages $(n=31)$

b Observations outside fruiting period in the Tamgak

O25-O26-O27 surprisingly displayed three alleles at three loci (DCA1; genotype 244-246-254; DCA8; genotype 121-135-139; EMO03; genotype 205-210218). Such a genetic pattern has recently been revealed in the olive complex for polyploid trees (Besnard et al. in press) and the diploid status of clone $\mathrm{O} 25-\mathrm{O} 26-\mathrm{O} 27$ can thus be questioned.

The efficiency of CG was evidenced with $28 \%$ of the genets being represented with two or more trees (clones). This ratio was significantly higher in the Bagzane (where it reached 40\%) than in the Tamgak (13\%; Pearson $\mathrm{Chi}^{2}=8.79, p \leq 0.01$, Table 1). Especially, it was higher than expected in ravines and on hillsides of the Bagzane mountains, unlike on wadi borders. The distance between clones was always less than $15 \mathrm{~m}$, except for $\mathrm{O} 73$ with $\mathrm{O} 71$ and $\mathrm{O} 72$ (Appendix).

The efficiency of CG was also demonstrated by the mean occurrence of 3.47 stems on each tree (Table 1). Single-stemmed trees were scarce (13\%) whereas a maximum number of 20 stems differentiated at the ground level were found on tree $\mathrm{O} 84$, in the Egalah mountains.

Habitat

The distribution of trees across habitats and massifs was uneven with a deficit of observed sites on the wadi borders of the Bagzane, compared to that of the Tamgak (Table 2).

A single type of trees was observed on wadi borders, with greater height and circumference (Table 3). The vegetation cover on wadi borders
Table 2 Observed (in italic) and theoretical (in regular) distributions of $O$. e. laperrinei genets among massifs and habitats $($ Pearson Chi-square $=17.12, p \leq 0.001)$

\begin{tabular}{lllcl}
\hline & Hillsides & Ravines & Wadi borders & Total \\
\hline Bagzane & 21 & 26 & 5 & 52 \\
& 17.51 & 20.69 & 13.80 & 52.00 \\
Tamgak & 12 & 13 & 21 & 46 \\
& 15.49 & 18.31 & 12.20 & 46.00 \\
Total & 33 & 39 & 26 & $98^{\mathrm{a}}$ \\
& 33.00 & 39.00 & 226.00 & $98.00^{\mathrm{a}}$ \\
\hline
\end{tabular}

${ }^{a}$ Genet O87-O88-O89-090 displayed two habitats (ravine and hillside)

and in ravines was more abundant than that found on hillsides. Lastly, the elevation of the sites located on the wadi borders of the Tamgak $(n=17)$ was higher than that of the sites in the other habitats $(n=60$; Table 3, Appendix).

\section{Associated species}

Among the trees and shrubs, Rhus tripartita and Acacia tortilis subsp. raddiana were the species the most frequently associated with $O$. e. laperrinei. They were similarly distributed in the Bagzane and the Tamgak mountains (Table 4), as well as the tropical trees Ficus cordata subsp. salicifolia, Ficus ingens var. ingens and Boscia salicifolia. Dichrostachys cinerea, another tropical tree, was especially frequent in the Bagzane. Among the herbaceous species, the grasses Cymbopogon schoenanthus and Chrysopogon plumulosus were frequent in the two massifs, whereas Tripogon multiflorus was 
Table 3 Variance analysis (ANOVA) of the shape and environment of individuals among habitats

\begin{tabular}{|c|c|c|c|c|c|}
\hline$n$ & $\begin{array}{l}\text { Hillsides } \\
28\end{array}$ & $\begin{array}{l}\text { Ravines } \\
32\end{array}$ & $\begin{array}{l}\text { Wadi borders } \\
17\end{array}$ & $F$-value & $p$ \\
\hline Height (m) & $3.69 \pm 0.17$ & $3.59 \pm 0.15$ & $4.60 \pm 0.21$ & 8.55 & $* * *$ \\
\hline Circumference (m) & $0.55 \pm 0.05$ & $0.53 \pm 0.04$ & $0.82 \pm 0.14$ & 4.58 & $*$ \\
\hline Vegetation cover $(\%)$ & $36 \pm 3$ & $24 \pm 3$ & $37 \pm 4$ & 4.83 & $*$ \\
\hline Elevation (m) & $1697 \pm 7$ & & $1731 \pm 12^{\mathrm{a}}$ & 5.30 & $*$ \\
\hline
\end{tabular}

a Wadi borders of the Tamgak uniquely

$* * * p \leq 0.001 ; * p \leq 0.05$

characteristic of the Bagzane. The saharo-mountainous Lavandula antinae was present in the Bagzane and the Tamgak at the same time.

\section{Discussion}

Distribution of the Laperrine's olive populations in the Aïr

Our observations confirm those previously made (Bruneau de Miré and Gillet 1956a) on the presence of O. e. laperrinei in the Bagzane and Tamgak mountains. A field mission conducted in the spring of 2006 also

Table 4 Occurrence of the most common species associated with $O$. e. laperrinei in the Bagzane and the Tamgak

\begin{tabular}{lll}
\hline Species & $\begin{array}{l}\text { Bagzane } \\
(n=28)\end{array}$ & $\begin{array}{l}\text { Tamgak } \\
(n=33)\end{array}$ \\
\hline Acacia tortilis subsp. raddiana & 22 & 28 \\
Acacia ehrenbergiana & + & 12 \\
Acacia laeta & + & 7 \\
Acacia seyal & + & 3 \\
Boscia salicifolia & + & + \\
Dichrostachys cinerea & 20 & 7 \\
Rhus tripartita & 26 & 30 \\
Carissa edulis & 1 & 0 \\
Commiphora africana & + & 0 \\
Ficus cordata subsp. salicifolia & + & + \\
Ficus ingens var. ingens & + & + \\
Lavandula antinae & 4 & 9 \\
Chrysopogon plumulosus & 22 & 16 \\
Tripogon multiflorus & 18 & 3 \\
Eragrostis pilosa & 19 & + \\
Cymbopogon schoenanthus & 15 & 30 \\
Pachycymbium decaisneanum & 1 & 0 \\
subsp. decaisneanum & & \\
\hline - quantive & &
\end{tabular}

+: quantitative data not available confirmed its existence in the Greboun mountains (Morel unpublished data). Aside from these three massifs, the highest in the Airr range, O. e. laperrinei was identified for the first time in the Egalah mountains and it has recently been reported in the Taghmert mountains, where it was observed by the former chief guide of the Nature Reserve (Tcholli unpublished data). The Laperrine's olive is thus distributed in five different massifs and not three (Fig. 2). It is suggested however that the respective sizes of the populations in the Egalah and the Taghmert mountains are very low $(\leq 40$ trees each?), given their modest elevation and their limited areas of distribution (Fig. 2).

The identification of a new population in the Bagzane (central zone) also enlarges the distribution area of the Laperrine's olive in the Air mountain range and extends its limit further to the South. The population size in the Bagzane remains nevertheless very low, similarly to the population sizes in the Greboun (Quézel 1962), the Egalah and the Taghmert mountains. It is thus in the Tamgak, in the centre of the Air range, where the largest population of $O$. e. laperrine $i$ is found.

Habitat comparison of the O. e. laperrinei populations in the Airr, the Hoggar and the western Darfur (Table 5)

A certain number of characteristics observed in the Airr mountain range are common to the entire area of distribution of the Laperrine's olive (Table 5). Thus, in all cases, they are located on relief at elevations higher than or equal to $1200 \mathrm{~m}$. In appearance, this tree remains generally bushy even though it can reach considerable heights (i.e., $7 \mathrm{~m}$ for tree O76). Finally, it seems that its favourite habitat is on the banks of temporary or permanent water courses (i.e., wadi border and ravine). 


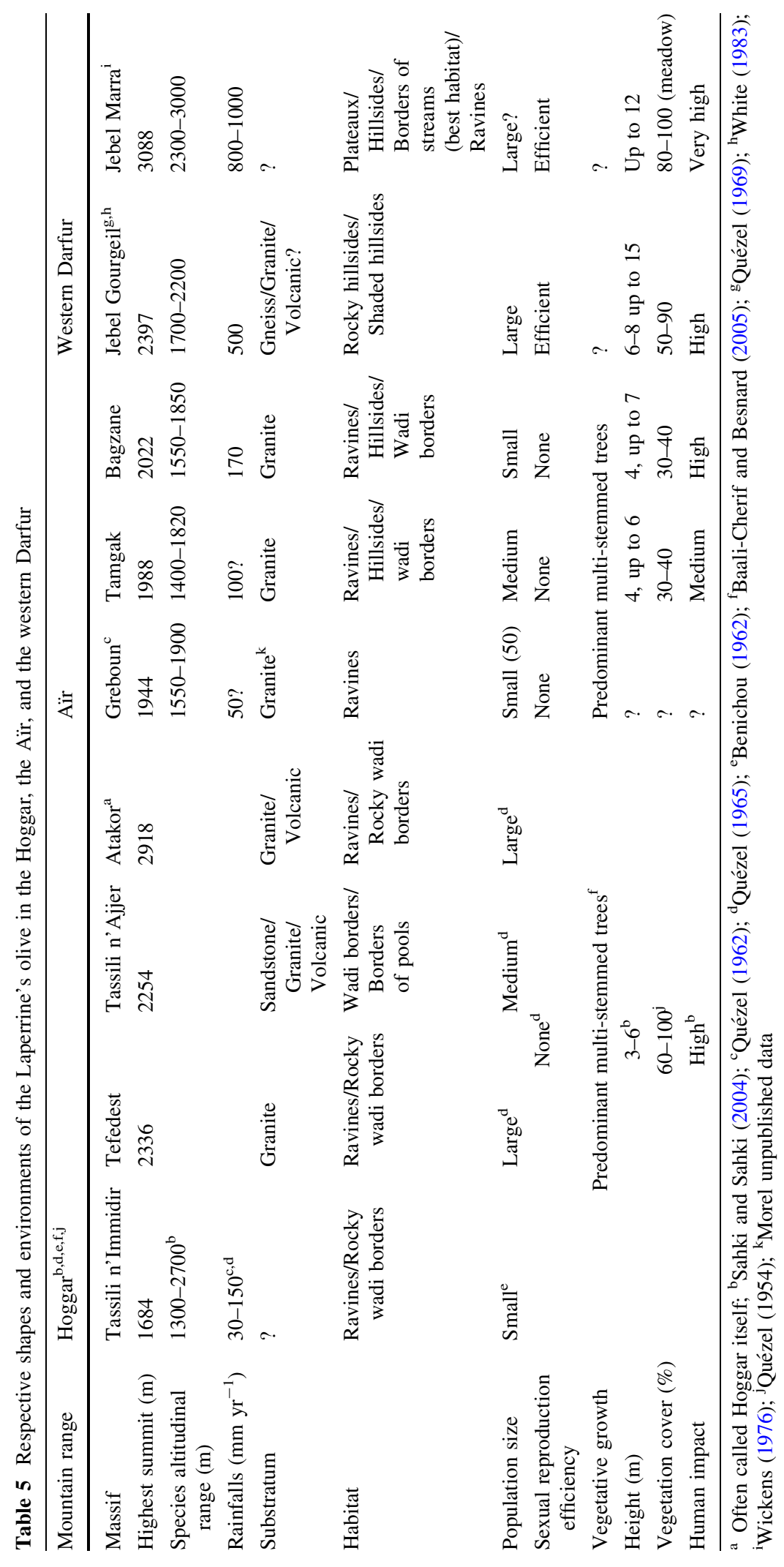


However, with regards to certain aspects, the populations found in the Air demonstrate distinctive characteristics explaining in part the small size and the fragmentation of its populations (Table 5). First, annual precipitations in the Air mountains, reaching $170 \mathrm{~mm} \mathrm{year}^{-1}$ in 2004-2005, like those in the Hoggar, are far weaker than those in the western Darfur (Table 5). Consequently, O. e. laperrinei in the Air and the Hoggar is restricted where water is available, i.e., wadi borders, ravines and hillsides, whereas it grows in very diverse habitats in the Darfur, including plateaux.

Unlike in the Hoggar however, the highest elevation in the Air is relatively low $(2022 \mathrm{~m})$, providing only a narrow altitudinal range of approximately $300 \mathrm{~m}$ for $O$. e. laperrinei to develop. Moreover, whereas the Hoggar is shaped with large massifs (Fig. 1), the Air displays small and isolated massifs in a matrix of low valleys where $O$. e. laperrinei cannot grow (Fig. 2). These multiple constraints act negatively on the size of populations but also on the habitats of $O$. e. laperrinei. Especially, the populations of the Aïr grow only on granite substratum, which provides better hydric conditions than volcanic substratum. In contrast, populations of the Hoggar grow on both substrata, giving birth to two distinct types of vegetation communities (Quézel 1965; Table 5).

Associated vegetation in the Hoggar is nevertheless different from that of the Airr, as most of the characteristic species (Stipa spp., Crambe kralikii, Pistacia atlantica) were not found in the Niger mountains. A substantial exception was the occurrence of Rhus tripartita, found frequently in granitic habitats in both mountains. In turn, Dichrostachys cinerea is a regular companion of $O$. e. laperrinei in the Air and the western Darfur (Quézel 1969; Wickens 1976) and is the most frequent representative of a pool of tropical species shared by these mountain ranges.

As a consequence, $O$. e. laperrinei in the Air presents unique characteristics. Sharing the aridity of the Hoggar, it displays a similar multi-stemmed short shape (Table 5) but sharing the tropical influence with the western Darfur, it displayed similarities with associated vegetation. Most of all, it is restricted to very small and fragmented areas that make it particularly sensitive to environmental changes.
Impact of human-related activities

The Bagzane mountains, located more in the South than the Tamgak mountains, present a water balance that is more favorable from rainfall and edaphic points of views owing to the presence of clay-sand plateaux (e.g., Ingram 1990). However, the Laperrine's olive is much less frequent there and has a tendency to colonize hillsides and ravines, which are inaccessible for people, rather than wadi borders, which provide more favorable conditions in a Saharan context (Quézel 1965) as is attested by the presence of taller trees in these habitats. This deficit is correlated with the ancient presence of settled populations on the Bagzane (Adamou and Morel 2005), which has had a much more significant impact than in the Tamgak mountains (Ingram 1990). It demonstrates that the human-related activities seem to have played an important role in the distribution of O. e. laperrinei in the Aïr, as it was shown in the Hoggar (Sahki and Sahki 2004) and the western Darfur (Quézel 1969; Wickens 1976; White 1983). Together with the current hyper-arid climatic period, they constitute a serious constraint for the development of O. e. laperrinei, especially expressed through a current lack of sexual reproduction.

Prevailing strategy of clonal growth

As a result of a defective sexual reproduction for both climatic and anthropogenic reasons, as in the Hoggar (Baali-Cherif and Besnard 2005) but not in the Darfur (Wickens 1976), the Aïr populations tend to become remnant populations sensu Honnay and Bossuyt (2005), using CG as a strategy of long-term persistence in a harsh environment that does not allow it to complete the normal life cycle. Its efficiency, represented through the ratio of genets represented by more than one tree, is high in comparison with other shrub species for which CG is a prevailing strategy of regeneration (e.g., 16\% for Spartocytisus supranubius; Kyncl et al. 2006). An interesting point of view is to match this ratio with the respective sizes of populations. The smallest population displayed the highest CG (Bagzane, 83 trees, $\mathrm{CG}=40 \%$ ) before the Tassili n'Ajjer (CG $=26 \%$; Besnard et al. in press), the Tamgak (about 2000 trees, $C G=13 \%$ ), and the Atakor (where several thousands of trees are 
present, $\mathrm{CG}=14 \%$; Besnard et al. in press). While facing relatively comparable aridity (e.g., Ozenda 2004), this variability in population size between the Tamgak and the Bagzane is interpreted as a response to a gradient of a pool of other environmental constraints (area availability, isolation, impact of human-related activities, habitat fragmentation) along which CG is increasingly used by $O$. e. laperrinei.

In conservation terms, $C G$ is interesting but it has a substantial cost. In one hand, it gives a potential longterm persistence to small-sized populations (Eriksson and Ehrlén 2001) especially because clones are less affected by browsing since shoots are more resistant than seedlings (Kyncl et al. 2006). In that case, regeneration is provided either with clonal-splitting strategy (Schenk 1999) or through integrator strategy, i.e., when trees keep interconnected and optimize the distribution of resources (Oborny et al. 2001; see the multi-stemmed characteristics of the trees). Long-term persistence of trees also slows down loss of genetic diversity through genetic drift (Young et al. 1996), which can become problematic with a high habitat fragmentation and a small population size (e.g., Richards 2000). But in the other hand, clonal populations should be more sensitive to stochastic events, like the proliferation of a pathogen agent (Honnay and Bossuyt 2005). It could also lead to sexual extinction sensu Honnay and Bossuyt (2005) because of successive mutations making genets not compatible at last (Klekowski 1997).

Altogether, the structure of $O$. e. laperrinei populations demonstrates that the current strategy for persistence within a hyper-arid context coupled with a human-related disturbance (browsing and cutting) is the CG. However, the occurrence of 98 different genets and the relatively short distance between trees demonstrates in all likelihood the former occurrence of a seeding phase, probably triggered during a less arid period as currently observed in the Jebel Marra (Wickens 1976). Adding to the fact that the age of trees in the Air mountain range has been estimated up to 2000 years (Quézel 1965), these results fit the model of multiple demographic strategies in arid and semi-arid environments, which states that CG coupled with longevity becomes a strategy of persistence in stressful environments, whereas periods of sexual regeneration take place when environmental constraints decrease (Garcia and Zamora 2003). To complete the model, we should add that disturbance, mainly represented here by browsing, is an important factor of strategy alternation (see also Kyncl et al. 2006).

\section{Long-term conservation?}

Even though the populations of $O$. e. laperrinei are distributed in several massifs in the Airr, they generally display a very small size (notably in the Bagzane mountains as probably in the Greboun, the Egalah and the Taghmert). As a consequence of the genetic drift and a limitation of gene flow at long distance, the genetic differentiation between Niger populations is relatively high when compared to southern Algerian mountains (Besnard et al. in press). Our demographic observations also sustain that the main centres of distribution of the Laperrine's olive are the Hoggar and the western Darfur. Even more than the current absence of sexual reproduction (which is temporarily compensated by clonal growth), interactions with human populations is a determining factor in the conservation of the Laperrine's olive in Niger where its limited distribution makes it more vulnerable than in all the other mountain ranges.

A long-term monitoring of the populations of the Lapperine's olive is today discussed in order to understand more precisely the nature of its interactions with people. They could be positive, for example through the sacred nature of rare or old trees as in the Egalah mountains or the Darfur (Wickens 1976), thus demonstrating the value of integrating local people into the conservation movement (McNeely 2003). Monitoring would also allow determining whether, during the course of a more favorable rainfall cycle, sexual reproduction could be triggered as in the Jebel Marra (Wickens 1976). It would certainly be relevant as well to test the hypothesis that human-related activities are the main factor of extinction of $O$. $e$. laperrinei in the mountain chains of the Ennedi and the Tibesti, which, as in the Air, are the biogeographical links between the Hoggar and the western Darfur.

Acknowledgements The authors thank Salouhou Djibrilla, Rhissa Bagzanamas, Vincent Simont and Haidara Attefock for their help in the field, Jean Maley for his advises on the manuscript, Luc Descroix for hydrologic support, and D. Taylor and D. Manley for linguistic advises. 
Appendix Distribution of sites $\left(n_{\text {site }}=78\right)$, trees $\left(n_{\text {tree }}=143\right)$ and genets $\left(n_{\text {genet }}=98\right)$ across the massifs of the Bagzane $(\mathrm{B})$, the Tamgak (T), and the Egalah (E). Coordinates expressed in UTM (32Q)

\begin{tabular}{|c|c|c|c|c|c|c|c|}
\hline Massif & Site & Trees & Habitat & Latitude & Longitude & Elevation (m) & [Clones] and missing data \\
\hline $\mathrm{B}$ & 1 & O1 & Hillside & 473815 & 1972072 & 1728 & {$[\mathrm{O} 1]$} \\
\hline $\mathrm{B}$ & 2 & $\mathrm{O} 2$ & Wadi border & 473848 & 1972145 & 1712 & {$[\mathrm{O} 2]$} \\
\hline B & 3 & $\mathrm{O} 3$ & Hillside & 473920 & 1972251 & 1729 & {$[\mathrm{O} 3]$} \\
\hline B & 4 & $\mathrm{O} 4-\mathrm{O} 5$ & Hillside & 474775 & 1972259 & 1735 & [O4-05] \\
\hline B & 5 & O6-O8 & Ravine & 474874 & 1972184 & 1703 & [O6-O7] and [08] \\
\hline B & 6 & O9-O16 & Ravine & 474878 & 1972245 & 1750 & $\begin{array}{l}\text { [O9-O10-011], [O12], [O14] } \\
\text { and [O15-O16]; O13 missing }\end{array}$ \\
\hline $\mathrm{B}$ & 7 & O17-O18 & Hillside & 474895 & 1972425 & 1755 & [O17-O18] \\
\hline B & 8 & O19 & Hillside & 475253 & 1973412 & 1770 & [O19] \\
\hline B & 9 & $\mathrm{O} 20-\mathrm{O} 21$ & Hillside & 475258 & 1973360 & 1775 & {$[\mathrm{O} 20]$ and $[\mathrm{O} 21]$} \\
\hline B & 10 & $\mathrm{O} 22-\mathrm{O} 23$ & Ravine & 475669 & 1973221 & 1765 & [O22-O23] \\
\hline B & 11 & $\mathrm{O} 24$ & Hillside & 475582 & 1973244 & 1755 & [O24] \\
\hline B & 12 & $\mathrm{O} 25-\mathrm{O} 28$ & Hillside & 475567 & 1973319 & 1755 & {$[\mathrm{O} 25-\mathrm{O} 26-\mathrm{O} 27]$ and $[\mathrm{O} 28]$} \\
\hline B & 13 & O29 & Ravine & 475501 & 1973365 & 1708 & [O29] \\
\hline B & 14 & $\mathrm{O} 30-\mathrm{O} 31$ & Hillside & 475503 & 1973370 & 1719 & [O30-O31] \\
\hline $\mathrm{B}$ & 15 & $\mathrm{O} 32$ & Ravine & 475482 & 1973445 & 1730 & [O32] \\
\hline B & 16 & $\mathrm{O} 33-\mathrm{O} 34$ & Ravine & 475477 & 1973491 & 1743 & [O33-O34] \\
\hline $\mathrm{B}$ & 17 & $\mathrm{O} 35-\mathrm{O} 36$ & Ravine & 474665 & 1966170 & 1710 & $\mathrm{O} 35$ and $\mathrm{O} 36$ missing \\
\hline B & 18 & O37-O39 & Ravine & 475635 & 1973595 & 1731 & [O37-O38] and [O39] \\
\hline B & 19 & $\mathrm{O} 40$ & Ravine & 475848 & 1973633 & 1740 & [O40] \\
\hline B & 20 & $\mathrm{O} 41-\mathrm{O} 44$ & Ravine & 475724 & 1973687 & 1741 & [O41], [O42] and [O43-O44] \\
\hline $\mathrm{B}$ & 21 & $\mathrm{O} 45, \mathrm{O} 50-\mathrm{O} 51$ & Hillside & 475910 & 1973830 & 1688 & [O45] and [O50-O51] \\
\hline $\mathrm{B}$ & 22 & O46 & Ravine & 475759 & 1973604 & 1677 & [O46] \\
\hline B & 23 & O47-O49 & Hillside & 475920 & 1973846 & 1705 & [O47-O48] and [O49] \\
\hline $\mathrm{B}$ & 24 & O52-O53 & Ravine & 475948 & 1973847 & 1691 & [O52] and [O53] \\
\hline B & 25 & O54 & Wadi border & 475879 & 1973862 & 1670 & [O54] \\
\hline B & 26 & O55-O56 & Ravine & 475159 & 1970217 & 1780 & [O55-O56] \\
\hline B & 27 & O57 & Ravine & 464741 & 1966528 & 1658 & O57 missing \\
\hline B & 28 & O58-O59 & Hillside & 475060 & 1960837 & 1800 & [O58]; O59 missing \\
\hline B & 29 & O60-O61 & Hillside & 474938 & 1960809 & 1690 & [060-061] \\
\hline B & 30 & O62-O63 & Ravine & 474172 & 1958868 & 1617 & [062-063] \\
\hline $\mathrm{B}$ & 31 & O64 & Ravine & 475365 & 1960146 & 1580 & [064] \\
\hline B & 32 & O65-O66 & Ravine & 477188 & 1960310 & 1595 & [O65-O66] \\
\hline B & 33 & O67 & Hillside & 472944 & 1961647 & 1550 & [O67] \\
\hline B & 34 & O68-O69 & Hillside & 471455 & 1961027 & 1628 & [068-069] \\
\hline B & 35 & $\mathrm{O} 70$ & Ravine & 465698 & 1956417 & 1672 & {$[\mathrm{O} 70]$} \\
\hline B & 36 & $\mathrm{O} 71-\mathrm{O} 72$ & Ravine & 475454 & 1961336 & 1677 & [O71-O72-O73] \\
\hline B & 37 & $\mathrm{O} 73$ & Ravine & 476152 & 1961101 & 1638 & \\
\hline B & 38 & O74 & Hillside & 476438 & 1974255 & 1620 & {$[074]$} \\
\hline B & 39 & O75 & Wadi border & 477274 & 1972323 & 1624 & {$[\mathrm{O} 75]$} \\
\hline B & 40 & O76-O78 & Wadi border & 472046 & 1973423 & 1662 & [O76-O77-O78] \\
\hline B & 41 & O79 & Ravine & 476436 & 1973873 & 1850 & [O79] \\
\hline $\mathrm{B}$ & 42 & O80-O81 & Hillside & 475620 & 1973517 & 1622 & [O80-O81] \\
\hline B & 43 & O82 & Hillside & 475726 & 1973610 & 1710 & O82 missing \\
\hline
\end{tabular}


Appendix continued

\begin{tabular}{|c|c|c|c|c|c|c|c|}
\hline Massif & Site & Trees & Habitat & Latitude & Longitude & Elevation (m) & [Clones] and missing data \\
\hline $\mathrm{B}$ & 44 & O83 & Wadi border & 475791 & 1973819 & 1765 & [O83] \\
\hline $\mathrm{E}$ & 45 & O84-O85 & Ravine & - & - & - & [084-O85] \\
\hline $\mathrm{T}$ & 46 & O86 & Hillside & 460065 & 2106994 & 1641 & [086] \\
\hline $\mathrm{T}$ & 47 & O87-O89 & Ravine & 460094 & 2106987 & 1645 & [087-O88-O89-O90] \\
\hline $\mathrm{T}$ & 48 & O90-O91 & Hillside & 460108 & 2106983 & 1648 & [091] \\
\hline $\mathrm{T}$ & 49 & O92-O93 & Hillside & 460961 & 2107141 & 1637 & [092-O93] \\
\hline $\mathrm{T}$ & 50 & O94 & Hillside & 460951 & 2107088 & 1640 & [094] \\
\hline $\mathrm{T}$ & 51 & O95 & Ravine & 460893 & 2107103 & 1635 & [095] \\
\hline $\mathrm{T}$ & 52 & O96 & Ravine & 460868 & 2107046 & 1653 & [096] \\
\hline $\mathrm{T}$ & 53 & O97 & Hillside & 460876 & 2106936 & 1682 & [097] \\
\hline $\mathrm{T}$ & 54 & O98-O99 & Ravine & 460798 & 2106954 & 1688 & [098-099] \\
\hline $\mathrm{T}$ & 55 & $\mathrm{O} 100$ & Hillside & 460786 & 2106944 & 1692 & [O100] \\
\hline $\mathrm{T}$ & 56 & O101-O102 & Ravine & 460754 & 2106906 & 1701 & [O101] and [O102] \\
\hline $\mathrm{T}$ & 57 & O103-0106 & Ravine & 460752 & 2106886 & 1704 & $\begin{array}{l}{[\mathrm{O} 103-\mathrm{O} 104],[\mathrm{O} 105] \text { and }} \\
{[\mathrm{O} 106]}\end{array}$ \\
\hline $\mathrm{T}$ & 58 & $\mathrm{O} 107$ & Ravine & 460742 & 2106847 & 1711 & [O107] \\
\hline $\mathrm{T}$ & 59 & $\mathrm{O} 108$ & Hillside & 460775 & 2106815 & 1712 & [O108] \\
\hline $\mathrm{T}$ & 60 & O109 & Hillside & 460839 & 2106833 & 1702 & [O109] \\
\hline $\mathrm{T}$ & 61 & $\mathrm{O} 110$ & Ravine & 460829 & 2106850 & 1701 & [O110] \\
\hline $\mathrm{T}$ & 62 & O111-O112 & Hillside & 460857 & 2106878 & 1693 & [O111] and [O112] \\
\hline $\mathrm{T}$ & 63 & $\mathrm{O} 113$ & Ravine & 460861 & 2106934 & 1684 & O113 missing \\
\hline $\mathrm{T}$ & 64 & $\mathrm{O} 114$ & Ravine & 463908 & 2107561 & 1708 & [0114] \\
\hline $\mathrm{T}$ & 65 & O115-O116 & Ravine & 463946 & 2107527 & 1716 & [O115-O116] \\
\hline $\mathrm{T}$ & 66 & O117-O122 & Wadi border & 464282 & 2107104 & 1792 & $\begin{array}{l}{[\mathrm{O} 117-\mathrm{O} 118-\mathrm{O} 119],[\mathrm{O} 120],} \\
{[\mathrm{O} 121] \text { and }[\mathrm{O} 122]}\end{array}$ \\
\hline $\mathrm{T}$ & 67 & O123-O125 & Wadi border & 464309 & 2107055 & 1802 & $\begin{array}{l}{[\mathrm{O} 123] \text { and }[\mathrm{O} 125] ; \mathrm{O} 124} \\
\text { missing }\end{array}$ \\
\hline $\mathrm{T}$ & 68 & $\mathrm{O} 126$ & Wadi border & 464263 & 2107215 & 1767 & [O126] \\
\hline $\mathrm{T}$ & 69 & O127-O128 & Wadi border & 464263 & 2107282 & 1752 & [O127] and [O128] \\
\hline $\mathrm{T}$ & 70 & O129-O132 & Wadi border & 464253 & 2107342 & 1810 & $\begin{array}{l}\text { [O129] and [O130]; O131 } \\
\text { and O132 missing }\end{array}$ \\
\hline $\mathrm{T}$ & 71 & $\mathrm{O} 133$ & Wadi border & 463390 & 2105462 & 1716 & [O133] \\
\hline $\mathrm{T}$ & 72 & O134 & Hillside & 463544 & 2105184 & 1725 & [O134] \\
\hline $\mathrm{T}$ & 73 & $\mathrm{O} 135$ & Wadi border & 463790 & 2104947 & 1740 & [O135] \\
\hline $\mathrm{T}$ & 74 & O136-O138 & Wadi border & 464624 & 2103950 & 1757 & [O136], [O137] and [O138] \\
\hline $\mathrm{T}$ & 75 & O139 & Wadi border & 464853 & 2103619 & 1698 & [O139] \\
\hline $\mathrm{T}$ & 76 & O140-O141 & Wadi border & 464904 & 2103597 & 1697 & [O140] and [O141] \\
\hline $\mathrm{T}$ & 77 & $\mathrm{O} 142$ & Wadi border & 464958 & 2103565 & 1738 & [O142] \\
\hline $\mathrm{T}$ & 78 & $\mathrm{O} 143$ & Wadi border & 464517 & 2103782 & 1729 & [O143] \\
\hline
\end{tabular}

\section{References}

Abdoun F, Beddiaf M (2002) Cupressus dupreziana A. Camus: distribution, decline and regeneration on the Tassili n'Ajjer, Central Sahara. C R Biol 325:617-627

Adamou A, Morel A (2005) Agadez et les montagnes de l'Aïr. La Boussole, Grenoble
Anthelme F, Cornillon L, Brun JJ (2002) Secondary succession of Alnus viridis (Chaix) DC. in the Vanoise National Park, France: coexistence of sexual and vegetative strategies. Ann For Sci 59:419-428

Anthelme F, Waziri-Mato M, de Boissieu D, Giazzi F (2006) Dégradation des ressources végétales au contact des activités humaines et perspectives de conservation dans le 
massif de l'Aïr (Sahara, Niger). Vertigo 7:1-12 (url: http://www.vertigo.uqam.ca/)

Anthelme F, Saadou M, Michalet R (2007) Positive associations involving the tussock grass Panicum turgidum Forssk. in the Aïr-Ténéré Reserve, Niger. J Arid Environ 68:348-362

Baali-Cherif D, Besnard G (2005) High genetic diversity and clonal growth in relict populations of Olea europaea subsp. laperrinei (Oleaceae) from Hoggar, Algeria. Ann Bot 96:823-830

Belaj A, Satovic Z, Cipriani G, Baldoni L, Testolin R, Rallo L, Trujillo I (2003) Comparative study of the discriminating capacity of RAPD, AFLP, and SSR markers and of their effectiveness in establishing genetic relationships in Olive. Theor Appl Genet 107:736-744

Benichou A (1962) Recherches critiques sur l'Olivier de Laperrine. Botanique Saharienne 6:1-55

Besnard G, Khadari B, Villemur P, Bervillé A (2000) Cytoplasmic male sterility in the Olive (Olea europaea L.). Theor Appl Genet 100:1018-1024

Besnard G, Khadari B, Baradat P, Bervillé A (2002) Olea europaea (Oleaceae) phylogeography based on chloroplast DNA polymorphism. Theor Appl Genet 104: 1353-1361

Besnard G, Rubio de Casas R, Vargas P (2007) Plastid and nuclear DNA polymorphism reveals historical processes of isolation and reticulation in the olive tree complex (Olea europaea L.). J Biogeogr 34:736-752

Besnard G, Christin PA, Baali-Cherif D, Bouguedoura N, Anthelme F (in press) Spatial genetic structure in the Laperrine's olive (Olea europaea subsp. laperrinei), a long-living tree from the Central-Saharan Mountains. Heredity. doi: 10.1038/sj.hdy.6801051

Besnard G, Garcia-Verdugo C, Rubio de Casas R, Treier UA, Galland N, Vargas P (in press) Polyploidy in the olive complex (Olea europaea L.): evidence from flow cytometry and nuclear microsatellite analyses. Ann Bot. doi: 10.1093/aob/mcm275

Black R, Jaujou M, Pellaton C (1967) Notice explicative sur la carte géologique de l'Aïr. BRGM, Paris

Bruneau de Miré P, Gillet H (1956a) Contribution à l'étude de la flore du massif de l'Aïr. Première partie. J Agric Trop Bot Appl 3:422-438

Bruneau de Miré P, Gillet H (1956b) Contribution à l'étude de la flore du massif de l'Aïr (suite et fin). Troisième partie, le milieu. J Agric Trop Bot Appl 3:857-886

Chapin III FS, Zavaleta ES, Eviner VT, Naylor RL, Vitousek PM, Reynolds HL, Hooper DU, Lavorel S, Sala OE, Hobbie SE, Mack MC, Diaz S (2000) Consequences of changing biodiversity. Nature 405:234-242

Child G (2003) Setting and achieving objectives for conserving biological diversity in arid environments. J Arid Environ 54:47-54

Database of the Flowering Plants of Africa South of the Sahara (2006) Conservatoire Botanique de Genève, Switzerland. http://www.ville-ge.ch/cjb/bd/africa/index.php (cited 21 May 2006)

Eriksson O, Ehrlén J (2001) Landscape fragmentation and the viability of plant populations. In: Silvertown J, Antonovics $\mathbf{J}$ (eds), Integrating ecology and evolution in a spatial context. Blackwell, London, pp 157-175
Gallaire R (1995) Hydrologie en milieu subdésertique d'altitude, le cas de l'Aïr (Niger). PhD thesis, University Paris XI, Orsay, France

Garcia D, Zamora R (2003) Persistence, multiple demographic strategies and conservation in long-lived Mediterranean plants. J Veg Sci 14:921-926

Giazzi F (1996) La Réserve Naturelle Nationale de l'Aïr et du Ténéré (Niger):_la connaissance des éléments du milieu naturel et humain dans le cadre d'orientations pour un aménagement et une conservation durables. MH/E, WWF, UICN, Gland, Switzerland

Green PS (2002) A revision of Olea L. (Oleaceae). Kew Bull 57:91-140

Hess J, Kadereit W, Vargas P (2000) The colonization history of Olea europaea L. in Macaronesia based on internal transcribed spacer 1 (ITS-1) sequences, randomly amplified polymorphic DNAs (RAPD), and inter-simple sequence repeats (ISSR). Mol Ecol 9:857-868

Honnay O, Bossuyt B (2005) Prolonged clonal growth: escape route or route to extinction? Oikos 108:427-432

Ingram GE (1990) Multi-gene-pool surveys in areas with rapid genetic erosion: an example from the Aïr mountains, Northern Niger. Conserv Biol 4:78-90

Klekowski EJ (1997) Somatic mutation theory of clonality. In: de Kroon H, van Groenandel J (eds), The ecology and evolution of clonal plants. Backhuys, Leiden, pp 227-241

Kyncl T, Suda J, Wild J, Wildova R, Herben T (2006) Population dynamics and clonal growth of Spartocytisus supranubius (Fabaceae), a dominant shrub in the alpine zone of Tenerife, Canary Islands. Plant Ecol 186:97-108

Le Houérou HN (1997) Climate, flora and fauna changes in the Sahara over the past 500 million years. J Arid Environ 37:619-647

McNeely JA (2003) Biodiversity in arid regions: values and perceptions. J Arid Environ 54:61-70

Maire R (1933) Etude sur la végétation du Sahara central. Mémoire de la Société d'Histoire Naturelle de l'Afrique du Nord, no 3, Mission du Hoggar II, Alger, pp 166-168

Maley J (1980) Les changements climatiques de la fin du Tertiaire en Afrique: leur conséquence sur l'apparition du Sahara et de sa végétation. In: Williams MAJ, Faure $\mathrm{H}$ (eds), The Sahara and the Nile. AA Balkema, Rotterdam, pp 63-86

Médail F, Quézel P, Besnard G, Khadari B (2001) Systematics, ecology, and phylogeographic significance of Olea europaea L. ssp. maroccana (Greuter \& Burdet). Bot J Linn Soc 137:249-266

Oborny B, Czaran T, Kun A (2001) Exploration and exploitation of a resource patch by clonal growth: a spatial model on the effect of transport between modules. Ecol Model 141:151-169

Ozenda P (2004) Flore et végétation du Sahara, 3rd edn. CNRS, Paris, France

Parks JC, Werth CR (1993) A study of spatial structure of clones in a population of bracken fern, Pteridium aquilinum (Dennstaedtiaceae). Am J Bot 80:120-126

Poilecot P (1996) Le milieu végétal de la Réserve Naturelle Nationale de l'Aïr et du Ténéré. In: Giazzi F (ed), La Réserve Naturelle Nationale de l'Aïr et du Ténéré (Niger): La connaissance des éléments du milieu naturel et humain dans le cadre d'orientations pour un aménagement et une 
conservation durables. MH/E, WWF, UICN, Gland, pp $121-180$

Poilecot P (1999) Les Poacées du Niger. UICN/CIRAD, Genève

Quézel P (1962) A propos de l'Olivier de Laperrine. In: Hugot HJ (ed), Missions Berliet Ténéré-Tchad. Flammarion, Paris, pp 329-332

Quézel P (1965) La Végétation du Sahara, du Tchad à la Mauritanie. Fischer-Verlag, Stuttgart

Quézel P (1969) Flore et végétation des plateaux du Darfur Nord-occidental et du Jebel Gourgeil. Dossiers de la RCP, vol 45. CNRS, Marseille

Quézel P (1978) Analysis of the flora of Mediterranean and Saharan Africa. Ann Mo Bot Gard 65:479-534

Richards CM (2000) Inbreeding depression and genetic rescue in a plant metapopulation. Am Nat 155:385-394

Sahki A, Sahki R (2004) Le Hoggar, promenade botanique. Esope, Lyon

Schenk J (1999) Clonal splitting in desert shrubs. Plant Ecol 141:41-52
Schulz E, Adamou A (1994) Le mont Bagzan (Aïr-Niger): exemple de seuil écologique dans le Sahara méridional. In: Bridel L, Morel A, Ousseini I (eds), Au contact Sahara-Sahel. Milieux et sociétés du Niger, vol II. Revue de géographie alpine, $\mathrm{N}^{\circ}$ hors-série, Ascendances, Grenoble, France, pp 43-63

Vargas P, Munoz Garmendia F, Hess J, Kadereit JW (2001) Olea europaea ssp guanchica and ssp maroccana (Oleaceae), two new names for olive tree relatives. An Jard Bot Madrid 58:360-361

Wickens GE (1976) The flora of Jebel Marra (Sudan Republic) and its geographical affinities. Kew Bull Add Ser 5:1-368

Vitousek PM, Hooper HA, Lubchenco J, Mellilo JM (1997) Human domination on Earth's ecosystems. Science 277:494-499

White F (1983) The vegetation of Africa. UNESCO, Paris

Young A, Boyle T, Brown T (1996) The population genetic consequences of habitat fragmentation for plants. Trends Ecol Evol 11:413-418 